OPEN ACCESS

Edited by:

Francesca Granucci,

University of Milano-Bicocca, Italy

Reviewed by:

Gunnar Houen,

Statens Serum Institut, Denmark

Taruna Madan,

National Institute for Research in

Reproductive Health, India

Roland Lang,

University Hospital Erlangen,

Germany

*Correspondence:

Gabriel Nussbaum

gabrieln@ekmd.huji.ac.il

tThese authors have contributed equally to this work.

Specialty section: This article was submitted to

Molecular Innate Immunity,

a section of the journal

Frontiers in Immunology

Received: 22 November 2016 Accepted: 09 May 2017

Published: 29 May 2017

Citation:

Dishon S, Cohen SJ, Cohen IR and Nussbaum $G$ (2017) Inhibition of Myeloid Differentiation Factor 88 Reduces Human and Mouse T-Cell Interleukin-17 and IFNy Production

and Ameliorates Experimental

Autoimmune Encephalomyelitis Induced in Mice.

Front. Immunol. 8:615. doi: 10.3389/fimmu.2017.00615

\section{Inhibition of Myeloid Differentiation Factor 88 Reduces Human and Mouse T-Cell Interleukin-17 and IFN $\gamma$ Production and Ameliorates Experimental Autoimmune Encephalomyelitis Induced in Mice}

\author{
Shira Dishon ${ }^{1 \dagger}$, Shmuel J. Cohen ${ }^{1,2 \dagger}$, Irun R. Cohen ${ }^{2}$ and Gabriel Nussbaum ${ }^{1 *}$
}

${ }^{1}$ Institute of Dental Sciences, Hebrew University-Hadassah Faculty of Dental Medicine, Jerusalem, Israel,

${ }^{2}$ Department of Immunology, Weizmann Institute of Science, Rehovot, Israel

Myeloid differentiation factor 88 (MyD88) recruits signaling proteins to the intracellular domain of receptors belonging to the toll-like/interleukin-1 (IL-1) receptor superfamily. Mice lacking MyD88 are highly susceptible to infectious diseases, but tend to resist experimentally induced autoimmune diseases such as experimental autoimmune encephalomyelitis (EAE) and manifest diminished allograft rejection. We reasoned that inhibition of MyD88 should influence the cytokine profile of responding T cells by blocking costimulatory molecule expression by antigen-presenting cells (APCs) and by inhibiting T-cell responses to IL-18. We now report that inhibition of MyD88 in human APCs led to decreased IFN $\gamma$ and IL-17 production and a shift to IL-4 production by responding T cells in a mixed lymphocyte reaction. Direct inhibition of Myd88 in mouse and human $\mathrm{T}$ cells also reduced their production of IFN $\gamma$ in response to IL-12/IL-18 stimulation. Finally, systemic MyD88 antagonism significantly reduced the clinical manifestations of EAE in mice. Thus, MyD88 appears to be a key factor in determining T cell phenotype and represents a potential target for therapeutic intervention.

Keywords: myeloid differentiation factor 88 , mixed lymphocyte reaction, experimental autoimmune encephalomyelitis, multiple sclerosis, Th1/Th2

\section{INTRODUCTION}

The cytokine environment present during T-cell priming and the costimulatory molecules expressed by antigen-presenting cells (APCs) play a determining role in CD4 T-cell functional differentiation (1). Dendritic cells (DCs) activated by toll-like receptor (TLR) ligands induce T-cell clonal expansion and lineage commitment through the production of cytokines such as interleukin (IL)-12 and IFN $\gamma$ (2). Myeloid differentiation factor 88 (MyD88) is an adaptor protein shared by TLRs and receptors for the proinflammatory cytokines IL-1 and IL-18. MyD88-dependent signals are critical to the development of Th1 and Th17 responses to foreign and self-antigens, both through the production of cytokines that induce differentiation and factors that suppress Th2 cell development $(3,4)$. In T cells, MyD88 is also expected to be critical for the response to IL- 1 and for IFN $\gamma$ production in response to 
IL-18. The net result of these effects is that CD4 Th responses in the absence of MyD88 are strongly skewed to production of Th2 and $\operatorname{Tr} 1$ cytokines (5-8).

We previously reported that TLR2 and TLR4 alone did not significantly contribute to experimental autoimmune encephalomyelitis (EAE), however MyD88 was required for EAE induction by active immunization with myelin antigen in Complete Freund's Adjuvant (CFA); MyD88-deficient mice immunized with MOG35-55 developed a population of IL-10-producing $\mathrm{T}$ cells that prevented EAE induced by adoptive transfer of encephalitogenic T cells. These cells also ameliorated EAE when transferred to wild-type mice undergoing active EAE (6). Given its central role in signal-transduction pathways that promote inflammatory Th1 development, MyD88 is an attractive target for therapeutic interventions in autoinflammatory and autoimmune diseases. MyD88 is composed of an N-terminal death domain and a C-terminal Toll/IL-1 receptor (TIR) domain separated by a short intermediary sequence (9). Following activation, MyD88 dimerizes and assembles a multiprotein complex that enables recruitment of the IL-1 receptor-associated kinases (IRAK)-4 and IRAK-1 and phosphorylation of TRAF6 (10, 11). MyD88 dimerization is dependent on a region within the TIR domain known as the BB loop that connects the second $\beta$-strand to the second $\alpha$-helix. A heptapeptide from this region competitively inhibits MyD88 dimerization and inhibits TLR/IL-1R signaling in vitro and in vivo $(10,12-14)$.

Herein, we determined the role of MyD88 in human T-cell phenotype modulation by inhibiting MyD88 in either the APCs or the T cells. Silencing MyD88 in APCs shut off IFN $\gamma$ and IL-17 production by alloreactive human CD4 $\mathrm{T}$ cells and shifted the response to IL-4 production. Targeting T-cell MyD88 blocked the response to IL-12/IL-18 stimulation. Furthermore, MyD88 inhibition in vivo in mouse EAE shifted the T-cell cytokine profile and led to reduced clinical signs of disease.

\section{MATERIALS AND METHODS}

\section{Cell Culture}

U-937, THP-1, and HeLa human cell lines (ATCC), and human and murine primary cells, were grown in RPMI or DMEM (Sigma) supplemented with fetal calf serum (FCS, 10\%), $4 \mathrm{mM}$ L-glutamine, $1 \mathrm{mM}$ sodium pyruvate, penicillin $(100 \mathrm{U} / \mathrm{mL})$, and streptomycin $(0.1 \mathrm{mg} / \mathrm{mL})$ (Biological Industries, Israel) at $37^{\circ} \mathrm{C}$ and 5\% $\mathrm{CO}_{2}$. U-937 and THP-1 monocytes were differentiated to macrophages with $5 \mathrm{ng} / \mathrm{mL}$ PMA (Cayman Chemical, Ann Arbor, MI, USA) for 3 days. Primary human $\mathrm{CD}^{+} \mathrm{T}$ cells and monocytes were purified from buffy coats by the RosetteSep Human $\mathrm{CD}^{+} \mathrm{T}$ or the RosetteSep human monocyte cell enrichment cocktail according to the manufacturer's instructions (StemCell Technologies, USA). Primary monocytes were differentiated to macrophages (confirmed by morphology and adhesion) with $10 \mathrm{ng} / \mathrm{mL}$ GM-CSF (Peprotec, Rehovot, Israel) for 6 days.

\section{Lentiviral Transduction of shRNA}

Five different MyD88 shRNA lentiviral transduction particles (Sigma) were independently transduced, and stable clones (of THP-1, U-937, and HeLa cells) were obtained based on resistanceto puromycin(Gold Biotechnology.St.Louis, MO, USA). The shRNA sequence that reduced human MyD88 to the greatest extent was 5'-CCGGCCTGTCTCTGTTCTTGAACGTCT CGAGACGTTCAAGAACAGAGACAGGTTTTTG-3'. Nontarget shRNA control cells were generated using an irrelevant sequence (Sigma). To transduce, cells were plated at $75 \%$ confluency $3 \mathrm{~h}$ prior to transduction and then the corresponding lentiviral particles were added at a Multiplicity of Infection of 10 overnight. After $48 \mathrm{~h}$, cells were selected by addition of medium containing $2 \mu \mathrm{g} / \mathrm{mL}$ puromycin for THP- 1 cells and $0.5 \mu \mathrm{g} / \mathrm{mL}$ for U-937 and Hela cells.

\section{mRNA Isolation and Reverse Transcription qPCR}

Total cellular RNA of the transduced cell lines was extracted using tri-reagent (Sigma) and the mRNA was reverse transcribed to cDNA with Maxima $\mathrm{H}$ minus Enzyme mix, according to the manufacturer's instructions (Thermo Scientific, Waltham, MA, USA). Amplification for qPCR was performed with primers to hMyD88 (forward 5'-ACAGGCACCAGCATACAC-3'; reverse $5^{\prime}$-TTGGGTCCTTTCCAGAGT-3') and hpactin (forward 5'-CACGGCATCGTCACCAACT-3'; reverse 5'-TGAT CTGGGTCATGTTCTCGC-3'). qPCR was performed using Bio-Rad CFX manager (Bio-Rad, Hercules, CA, USA) and the reactions with KAPA SYBR Fast ABI prism (KAPA systems, Salt River, Cape Town). The final results were calculated by dividing the relative transcript levels of the test genes by the relative amount of $\beta$ actin RNA.

\section{Western Blot}

For MyD88 protein detection, $10^{7}$ cells were lysed in Ripa buffer in the presence of protease inhibitors and incubated on ice for $25 \mathrm{~min}$. The lysates were then centrifuged at $10,000 \mathrm{~g}$ for $15 \mathrm{~min}$. Proteins were separated by gel electrophoresis and transferred to nitrocellulose membranes. The nitrocellulose membranes were blocked with 5\% skim milk for $1 \mathrm{~h}$ and MyD88 was detected using $1 \mu \mathrm{g} / \mathrm{mL}$ polyclonal rabbit anti-MyD88 (eBioscience, San Diego, CA, USA) followed by $100 \mathrm{ng} / \mathrm{mL}$ goat anti-rabbit IgG-HRP (Abcam, Cambridge, UK). After washing extensively with Trisbuffered saline (TBS) containing $0.2 \%$ Tween 20 , the membranes were exposed to chemiluminescent substrate in the presence of hydrogen peroxide, using the EZ-ECL-chemiluminescence detection kit (Biological Industries, Israel). A Gel-Doc imaging system (Bio-Rad, Hercules, CA, USA) was used to capture the image.

\section{Flow Cytometry}

THP- 1 cells were seeded at $1.5 \times 10^{6}$ in six well plates with $5 \mathrm{ng} / \mathrm{mL}$ PMA (Cayman Chemical, Ann Arbor, MI, USA) for 3 days differentiation. When indicated, $100 \mathrm{ng} / \mathrm{mL}$ Pam $3 \mathrm{csk} 4$ (Invitrogen, San Diego, CA, USA) + 20 ng/mL IFN $\gamma$ (Peprotec, Rehovot, Israel) was added to the cells for the final $24 \mathrm{~h}$ of incubation to induce differentiation (concentrations of stimulants were determined in preliminary calibration experiments). Cells were then collected, washed, and stained using APC-conjugated humanspecific antibodies (Biolegend, San Diego, CA, USA) to CD80, 
HLA-A2, and HLA-DR for $30 \mathrm{~min}$ on ice. The purity of CD4 ${ }^{+}$ $\mathrm{T}$ cells isolated from buffy coats of healthy donors was confirmed by flow cytometry using FITC-anti-CD4 (Tonbo Biosciences, San Diego, CA, USA). Intracellular cytokine staining was analyzed on T cells incubated for 6 days with APCs. Cells were incubated with cell stimulation cocktail (eBioscience, San Diego, CA, USA) and Brefeldin (Biolegend, San Diego, CA, USA) for $6 \mathrm{~h}$ prior to collection, and then fixed $15 \mathrm{~min}$ at RT. Cells were then permeabilized and stained with Leucoperm permibilization reagent (AbD Serotec, Kidlington, UK) and APC-anti-IL-4 (Biolegend, San Diego, CA, USA) for 30 min on ice. Samples were analyzed using a BD LSRII flow cytometer or a BD ACCURI C6 cytometer (BD Biosciences, San Jose, CA, USA), and data were analyzed using FCS Express software (De Novo Software, Glendale, CA, USA).

\section{Analysis of p65 Nuclear Translocation}

Hela shCnt and HeLa shMyD88 cells were activated with $20 \mathrm{ng} / \mathrm{mL}$ IL- $1 \beta$ or $10 \mathrm{ng} / \mathrm{mL}$ TNF $\alpha$ (ProSpec, Rehovot, Israel) for $30 \mathrm{~min}$ or $1 \mathrm{~h}$, respectively. Cells were then fixed (3.7\% PFA in PBS for $10 \mathrm{~min})$, permeabilized $(0.25 \%$ Triton-X100) and blocked (2\% BSA in TBS) at $4^{\circ} \mathrm{C}$ for $16 \mathrm{~h}$. Cells were then stained with $0.6 \mu \mathrm{g} / \mathrm{mL}$ rabbit anti-p65 in 2\% BSA in TBS (Santa Cruz Biotechnology, Dallas, TX, USA) followed by $0.5 \mu \mathrm{g} / \mathrm{mL}$ CY-3 goat anti-rabbit antibody (Jackson ImmunoResearch, Baltimore Pike, PA, USA). Cytoplasmic vs. nuclear localization was analyzed by fluorescent microscopy (15) (Nikon-Ti microscope).

\section{Peptides}

Myeloid differentiation factor 88 inhibitor peptide (MyDI) (RDVLPGT), or the scrambled version of the same sequence, (MyDI-sc) (PTDLVRG), were synthesized in the Weizmann Institute of Science and purified by HPLC.

\section{Mixed Lymphocyte Reaction (MLR)}

shMyD88 THP-1 vs. shCnt THP-1 cells were differentiated as above with PMA alone or PMA with Pam3csk4/IFN $\gamma$. Cells were treated with $10 \mu \mathrm{g} / \mathrm{mL}$ Mitomycin c (Sigma) to prevent replication, and added in various concentrations to CD4 ${ }^{+} \mathrm{T}$ cells in 96 well round bottom plates (Thermo Scientific). T-cell proliferation and cytokine production were analyzed after 6 days of coculture. Proliferation was assayed using a non-radioactive Tetrazoliumbased kit (Promega, Madison, WI, USA) according to the manufacturer's instructions.

Primary human macrophages were incubated for $24 \mathrm{~h}$ with or without $80 \mu \mathrm{M}$ MyDI vs. MyDI-sc peptides. Macrophages were treated with $10 \mu \mathrm{g} / \mathrm{mL}$ mitomycin c (Sigma) to prevent replication and added in various concentrations to $\mathrm{CD} 4^{+} \mathrm{T}$ cells in 96-well round bottom plates (Thermo Scientific). T-cell proliferation and cytokine production were analyzed after 6 days of coculture. Proliferation was assayed using a non-radioactive Tetrazolium-based kit (Promega, Madison, WI, USA) according to the manufacturer's instructions.

\section{MyD88 Inhibition of Mouse MOG-Specific T Cells and Human CD4 ${ }^{+}$T Cells}

Anti-MOG35-55 resting T cells were treated in vitro with MyDI or MyDI-sc $(20 \mu \mathrm{M})$ prior to stimulation with IL-18 $(30 \mathrm{ng} / \mathrm{mL})$
(R\&D systems, Inc., Minneapolis, MN, USA). The effect of MyDI or MyDI-sc was also tested on anti-MOG35-55 resting T cells re-stimulated with MOG35-55 $(5 \mu \mathrm{g} / \mathrm{mL})$ in the presence of irradiated splenocytes with or without the addition of IL-18. Cytokines were measured in the cell supernatants after overnight incubation. Primary human $\mathrm{CD} 4^{+} \mathrm{T}$ cells that were isolated from buffy coats were incubated for $3 \mathrm{~h}$ in the absence or presence of MyDI, or MyDI-sc $(20 \mu \mathrm{M})$ and stimulated with IL-18 + IL-12 (320 and 160 ng/mL, respectively) overnight (Peprotec, Rehovot, Israel). Cytokines were measured in the cell supernatants after overnight incubation.

\section{Mice}

C57BL/6 (B6) mice were purchased from Harlan (Jerusalem, Israel). Female, 8 - to 14 -week-old mice were used in the experiments. The mice were housed at the SPF units of our universities and all experiments were approved by the Hebrew UniversityHadassah Institutional Animal Care and Use Committee (protocol number 16-14745).

\section{Draining Lymph Node (DLN) Cell Activation}

Mice immunized s.c. with $100 \mu \mathrm{g} \mathrm{MOG}_{35-55} / \mathrm{CFA}$ and treated with MyDI and control were sacrificed 11 days after immunization, and popliteal, inguinal, and axillary LNs were collected and single cell suspensions were prepared. Cells were cultured in 96-well plates $\left(0.5 \times 10^{6}\right.$ per well $)$ for $72 \mathrm{~h}$ with or without increasing concentrations of Myelin Oligodendrocyte Glycoprotein ( $\mathrm{MOG}_{35-55}$ ) or purified protein derivative (PPD) or ovalbumin (OVA) peptide in the culture.

\section{Induction of EAE and Treatment}

For in vivo treatment, we synthesized the MyDI or MyDIscr peptides with a basic peptide from the Drosophila Antennapedia homeodomain (DRQIKIWFQNRRMKWKK) at the C-terminus [12]. All peptides were synthesized at the Weizmann Institute of Science and purified by HPLC. Mice were immunized s.c. in the flank with $200 \mu \mathrm{g}^{\mathrm{MOG}} \mathrm{G}_{35-55}$ emulsified in CFA supplemented with $300 \mu \mathrm{g}$ Mycobacterium tuberculosis (Mt) H37RA (Difco). Pertussis Toxin (PTX, List Biological Laboratories, CA, USA) was injected i.v. at the time of immunization and $48 \mathrm{~h}$ later. In some experiments, animals were sacrificed prior to onset of clinical symptoms in order to analyze the lymph node response. EAE was scored on a scale of 0-6: 0, no impairment; 1 , limp tail; 2 , limp tail and hind limb paresis; 3, $\geq 1$ hind limb paralysis; 4 , full hind limb and hind body paralysis; 5 , hind body paralysis and front limb paresis; and 6, death. Mice were treated with MyDI i.p. (2 mg/kg) vs. control at day 0 and every $48 \mathrm{~h}$.

\section{Cytokine Analysis}

Levels of hTNF- $\alpha$, h INF- $\gamma$ and hIL-17 and mIL-10, mIL-5, mIL17 , and $\operatorname{mINF}-\gamma$ were determined using human/mouse OptEIA sets (BD Biosciences, CA, USA) according to the manufacturer's instructions. 


\section{Statistical Analysis}

The two-tailed $t$-test was used for statistical evaluation of all the results except the two-way analysis of variance test that was used for the EAE model assay. Values are shown for data that reached a significance of $P \leq 0.05\left(^{*}\right), P \leq 0.01\left(^{* *}\right), P \leq 0.005,\left({ }^{* *}\right)$, and $P \leq 0.001\left(^{* * *}\right)$. Bars show mean and SD and in Figure 6D SEM (Prism v.5, GraphPad Software Inc., San Diego, CA, USA).

\section{RESULTS}

\section{Silencing MyD88 with shRNA Specifically Blocks the Response of Human Cell Lines to TLR/IL-1 Stimulation}

To determine the role of MyD88 in human APCs, we first established stable shRNA knock-down cells. We screened lentivirally expressed shRNA sequences in HeLa cells to find a sequence that reduced MyD88 efficiently and did not affect inflammatory pathways driven by other signals. Sequences that reduced MyD88 mRNA expression also blocked NFKB nuclear translocation in response to IL-1 stimulation, a MyD88-dependent event, but had no effect on $\mathrm{NF \kappa B}$ translocation in response to $\mathrm{TNF} \alpha$ stimulation that occurs independently of MyD88 (Figure 1B). Control shRNA transduction did not affect either signaling pathway (Figure 1A). We next transduced human THP-1 monocyte/macrophage cells with this shRNA and found efficient reduction of MyD88 mRNA and protein (Figure S1 in Supplementary Material), and a near complete reduction in the response to stimulation with PAM3Csk4, a synthetic triacylated lipopeptide ligand of TLR2/ TLR1 (Figure 1C).

\section{MyD88 Silencing Blocks the Induction of Macrophage CD80 But Does Not Affect HLA Expression in Human APCs}

To probe the effect on T-cell phenotype of silencing MyD88 in APCs, we first tested costimulatory molecule (CD80) and HLA expression in shMyD88 compared to shCnt THP-1 cells

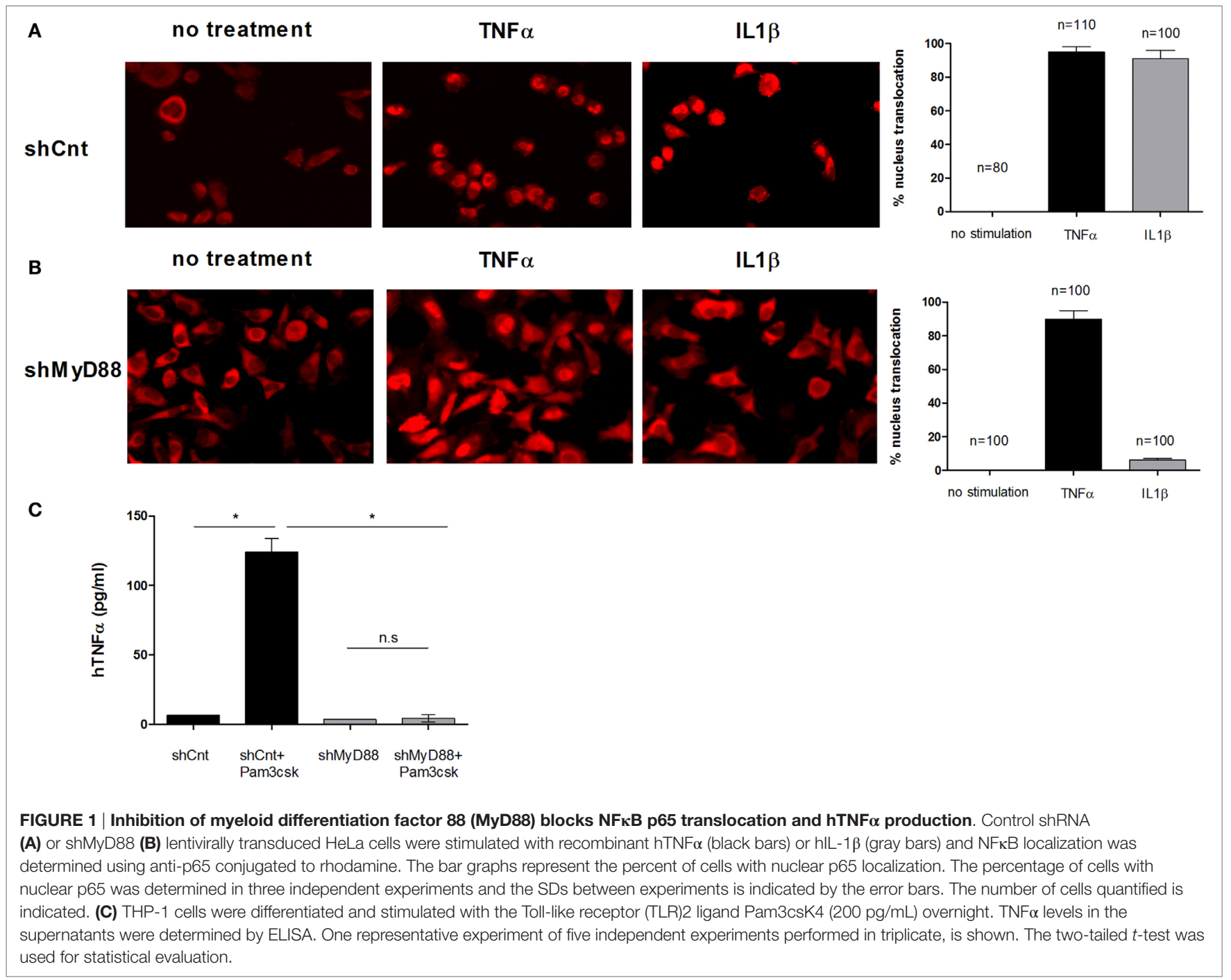


differentiated with PMA and further stimulated with Pam3csk4/ IFN $\gamma$. We focused on CD80 since CD86 expression was not strongly upregulated in response to stimulation with Pam3csk4/ IFN $\gamma$. In shCnt cells, Pam3csk4 alone induces CD80 expression which is further enhanced by addition of IFN $\gamma$ (Figures 2A,B). Silencing MyD88 prevented the induction of CD80 expression in response to Pam $3 \mathrm{csk} 4 / \mathrm{IFN} \gamma$ (Figures 2A,C), since enhanced CD80 expression is mostly due to TLR2 stimulation by PAM3csk4 (Figures 2B,C). However, the induction of HLA expression (both class I and class II), an effect attributable to IFN $\gamma$ stimulation (Figures 2E,F), remained intact in the absence of MyD88 (Figures 2D-F; Figure S2 in Supplementary Material). Interestingly, Pam3csk4 reduced the basal level of MHC-II expression in differentiated shCnt THP1 cells (Figure 2E); however, this effect was not seen in the WT THP1 cells (not shown). Therefore, MyD88 affects the regulation of costimulatory signals without inhibiting the regulation of HLA.

\section{MyD88 Knockdown APCs Induce T Cell Proliferation with Enhanced IL-4 Production and Lowered IFN $\gamma$ and IL-17 Production}

We next performed a MLR using the shMyD88 compared to shCnt THP- 1 cells. The THP-1- transfected cells were differentiated for 3 days, and during the final $24 \mathrm{~h}$ the cells were stimulated with Pam3csk4/IFN $\gamma$. The THP-1 cells were treated with Mitomycin $c$ to prevent their proliferation, and then seeded together with $\mathrm{CD}^{+}$cells isolated from buffy coats. After 6 days, we measured T-cell proliferation and cytokine production. ShCnt and shMyD88 APCs induced T-cell proliferation to a similar extent (Figures 3E,F, no significant differences were detected between the proliferation induced by each type of APC). Nevertheless, there was a marked difference in the cytokine profile of the proliferating T cells. Whereas shCnt APCs induced IFN $\gamma$ (Figure 3A) and IL-17 (Figure 3C) in a concentration-dependent manner, there was no production of either of these cytokines by $\mathrm{T}$ cells stimulated with shMyD88 APCs (Figures 3B,D). In contrast, the shMyD88 APCs induced IL-4-producing T cells, which were not present in the cultures of cells stimulated with shCnt APCs (Figures 3G,H).

To strengthen the results, we next examined the effect of MyD88 inhibition using primary human APCs and an additional means of MyD88 inhibition. To block MyD88, we incubated differentiated primary macrophages with the MyD88 inhibitory BB loop peptide (MyDI) (12), and as a control we used a scrambled control peptide (MyDI-sc). MyDI treatment specifically blocks MyD88-dependent signaling, as demonstrated by reduced $\mathrm{NF \kappa B}$ activation in response to IL-1, but not in response to $\mathrm{TNF} \alpha$ stimulation. In contrast, MyDI-sc does not inhibit $\mathrm{NF \kappa B}$ activation in response to either stimulant (Figure S4 in Supplementary Material). MyDI treatment also blocks inflammatory cytokine production by primary cells or THP- 1 cells activated with the TLR2 ligand Pam 3 csk4, although to a lesser extent than shRNA inhibition (Figures S5A,B in Supplementary Material). Primary APCs were treated with Mitomycin $c$ to prevent their proliferation, and then seeded together with donor-mismatched $\mathrm{CD}^{+} \mathrm{T}$ cells isolated from buffy coats. After 6 days, we measured T-cell proliferation and cytokine production. Inhibition of MyD88 did not affect the ability of primary APCs to induce T cell proliferation (Figure 4C), however inhibition shifted the cytokine profile of the proliferating T cells. Similar to our findings using shMyD88 THP-1 cells, peptide inhibition of MyD88 in primary APCs led to significantly diminished IFN $\gamma$ and IL-17 by responding $\mathrm{T}$ cells, and a shift to IL-4 production (Figures 4A,B,D). Importantly, peptide blocking of MyD88, a less efficient method compared to stable shRNA inhibition, produced a similar effect. Similar results were obtained when primary human DCs were used as APCs (data not shown). Therefore, MyD88 inhibition in human APCs induces a shift in the cytokine profile of responding $\mathrm{T}$ cells from IFN $\gamma$ and IL-17 production to IL-4 production without significantly reducing $\mathrm{T}$-cell proliferation.

\section{MyD88 Inhibitor Peptide Reduces IFN $\gamma$ Secreted by IL-18 \pm IL-12 Stimulated Human and Mouse T-Cells}

Since MyD88 functions downstream to multiple receptors expressed by T cells, we next asked if inhibition of T-cell MyD88 would effectively reduce cytokine production. In contrast to THP-1 cells, we found that the MyDI peptide penetrated primary T cells efficiently (Figure S3 in Supplementary Material), obviating the need for shRNA. To investigate the effect of MyD88 inhibition on primary human $\mathrm{T}$ cell antigen-independent IFN $\gamma$ production (16), cells were incubated with MyDI or MyDI-sc and then stimulated overnight with IL-18 + IL-12. hIFN $\gamma$ secretion was abolished in the stimulated cells by the addition of MyDI but was not decreased in the cells treated with the MyDI-sc (Figure 5A). To test if similar effects could be obtained in autoimmune $\mathrm{T}$ cells, we treated $\mathrm{MOG}_{35-55}$-specific murine $\mathrm{T}$ cells with MyDI and MyDI-sc prior to IL-18 stimulation. MyDI treatment significantly reduced IL-18-stimulated IFN $\gamma$ secretion, in contrast to treatment with MyDI-sc (Figure 5B). We next tested the effect of MyDI on the cytokine response of $\mathrm{MOG}_{35-55}$-specific T cells responding to antigen stimulation in the presence of IL-18 and $\mathrm{MOG}_{35-55}$ peptide (Figure 5C). IL-18 treatment increased the IFN $\gamma$ response of antigen-specific T cells. Here too, MyDI treatment significantly reduced the level of IFN $\gamma$ when IL-18 was present (Figure 5C).

\section{MyD88 Inhibitor Peptide Alters the Cytokine Profile of the Inflammatory Response In Vivo and Attenuates EAE}

To investigate the in vivo effects of MyDI treatment on the $\mathrm{T}$ cell cytokine profile, we immunized mice with $\mathrm{MOG}_{35-55}$ peptide emulsified in CFA and administered PTX on day 0 and at $48 \mathrm{~h}$. The mice were treated i.p. on day 0 and every $48 \mathrm{~h}$ with $2 \mathrm{mg} /$ $\mathrm{kg}$ MyDI or MyDI-sc or PBS. Eleven days following immunization, the DLNs were harvested and cells were activated ex vivo with increasing doses of $\mathrm{MOG}_{35-55}$ or increasing doses of PPD, representing major antigens of the $\mathrm{Mtb}$ in the adjuvant. Cytokine secretion was analyzed $72 \mathrm{~h}$ after activation. As shown in Figure 6, MyDI treatment induced a shift in the cytokine profile of the 
$\square$ Cells w ithout PMA

$\square$ Cells w ith PMA

$\square$ Cells w ith PMA+Pam3csk+IFNy

A

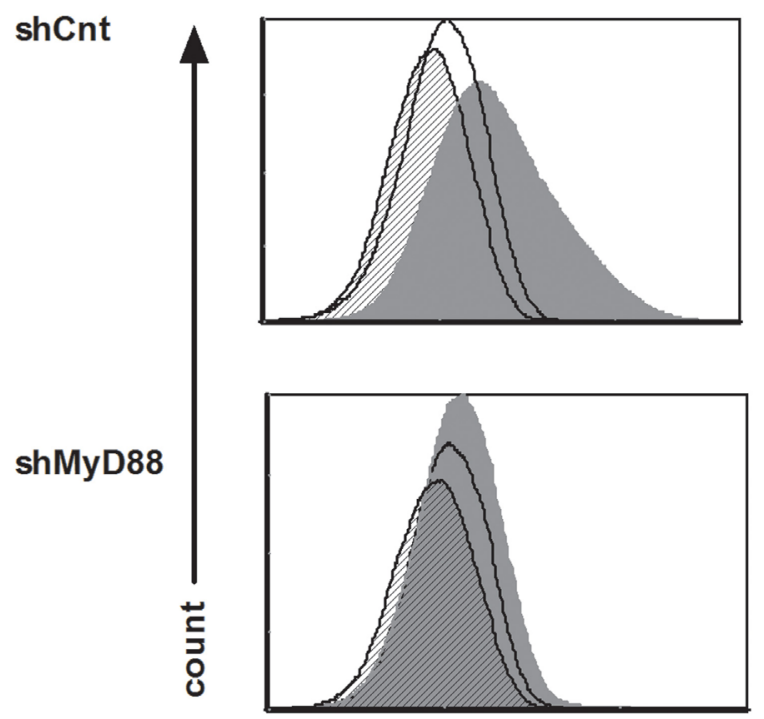

B

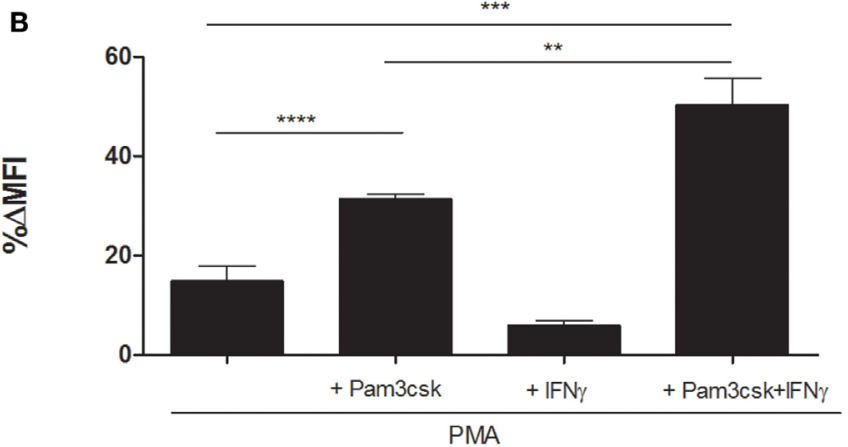

shCnt

$c$
$\frac{5}{5}$

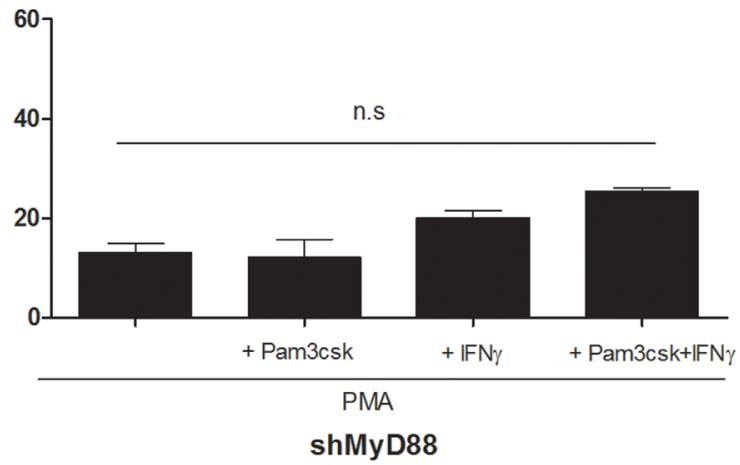

D

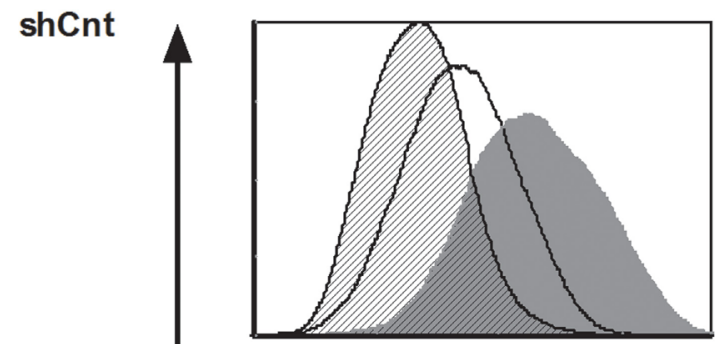

shMyD88
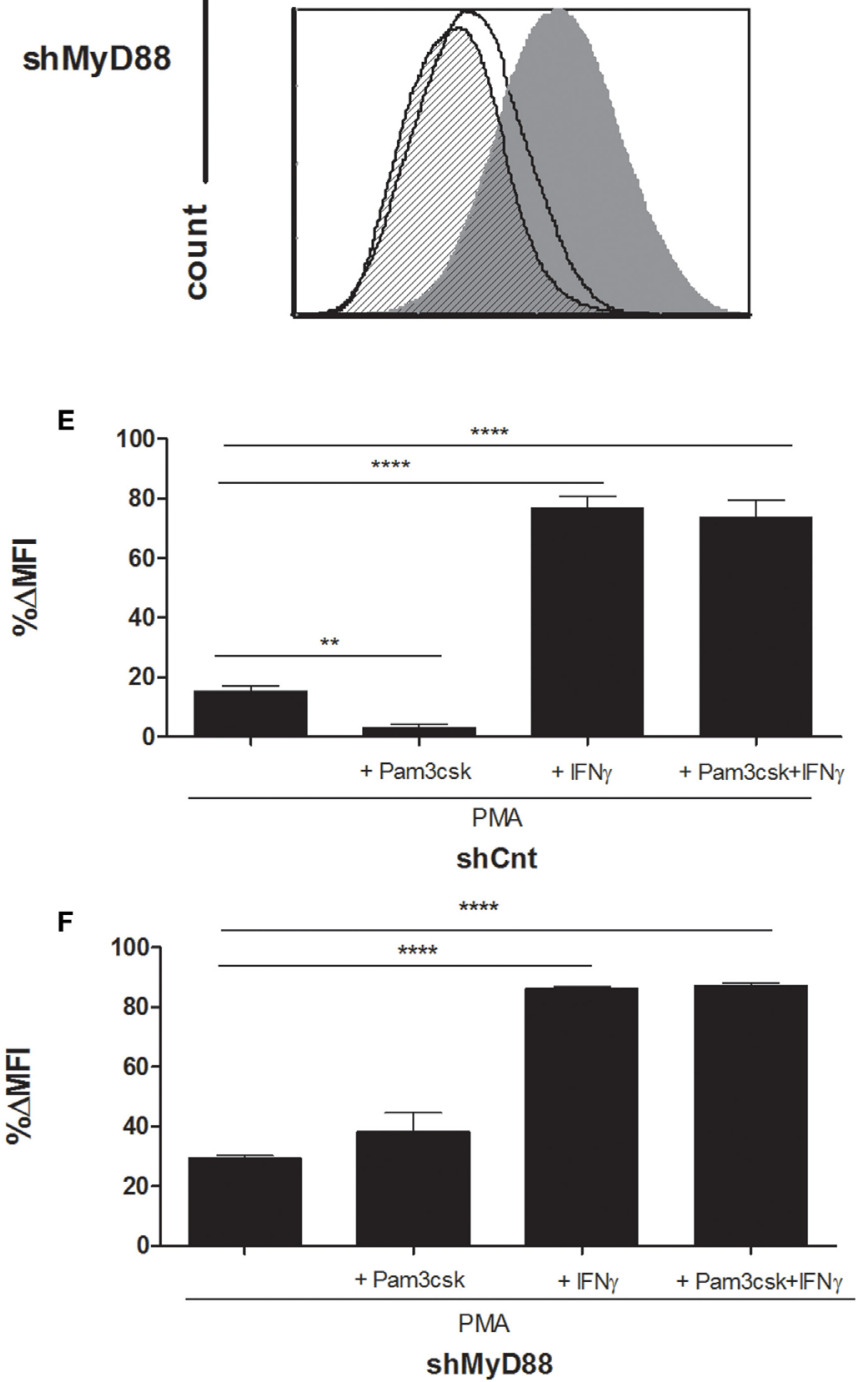

FIGURE 2 | Myeloid differentiation factor 88 (MyD88) knockdown blocks the induction of macrophage CD80 expression without affecting HLA-DR in response to Toll-like receptor (TLR) ligands. Control (shCnt) vs. shMyD88 transduced THP-1 cells were differentiated for $72 \mathrm{~h}$ with PMA, with the addition of $100 \mathrm{ng} / \mathrm{mL}$ Pam3csk4, $20 \mathrm{ng} / \mathrm{mL}$ IFN $\gamma$, or $100 \mathrm{ng} / \mathrm{mL}$ Pam3csk4 $+20 \mathrm{ng} / \mathrm{mL}$ IFN $\gamma$. For the final $24 \mathrm{~h}$. Cells were then analyzed for CD80 (A-C) and HLA-DR (D-F) expression by flow cytometry. Data in panels $(\mathbf{B}, \mathbf{C}, \mathbf{E}, \mathbf{F})$ are presented as \% difference in intensity between each group ( $\Delta$ MFI). Representative histograms (A,D) and combined data of triplicates from two independent experiments are shown $(\mathbf{B}, \mathbf{C}, \mathbf{E}, \mathbf{F})$. The two-tailed $t$-test was used for statistical evaluation. 
A

shCnt

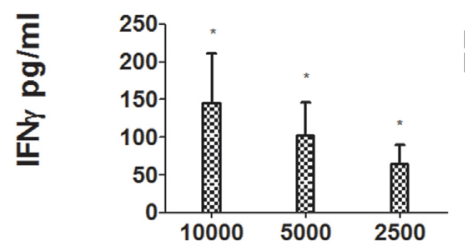

no. of APCs added

C

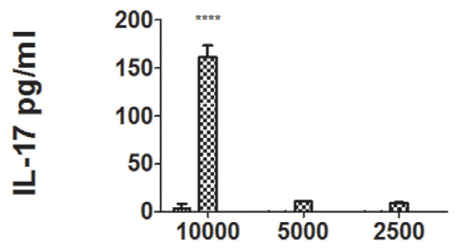

E - no. of APCs added

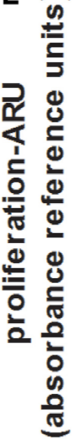

G
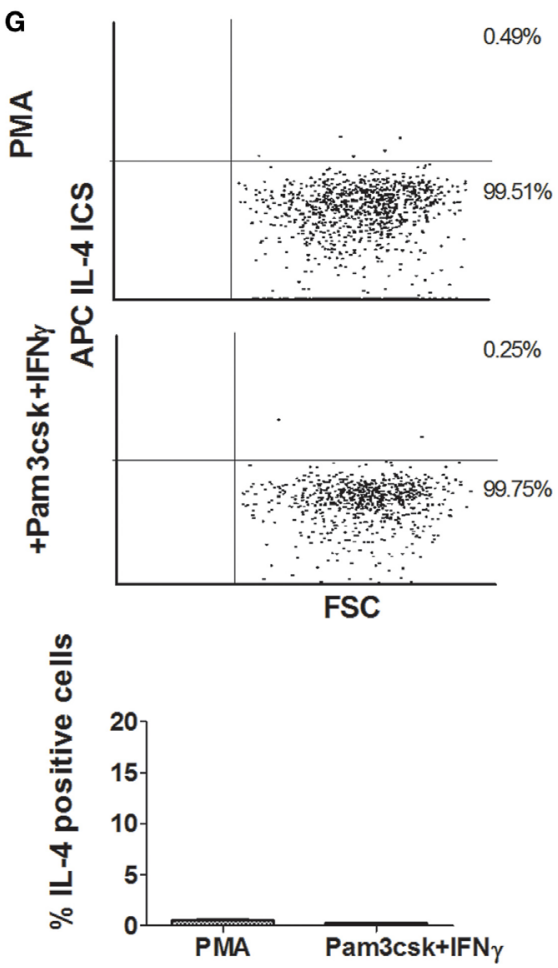

PMA

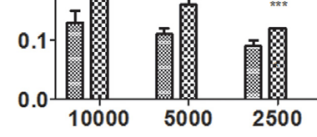

no. of APCs added
B shMyD88

+ Pam3csk+IFN $\gamma$

+ Pam3csk+IFN $\gamma$
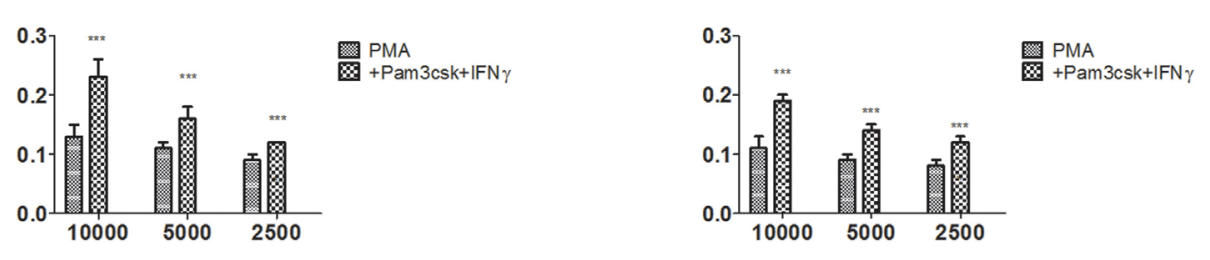

no. of APCs added

$D$

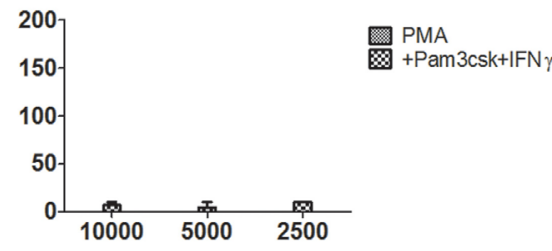

no. of APCs added

$\mathbf{F}$

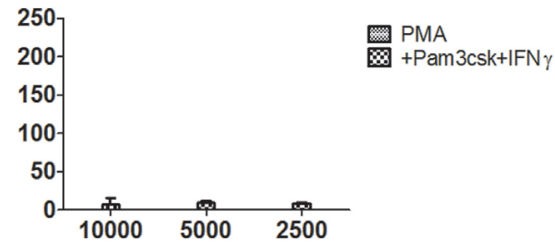

no. of APCs added
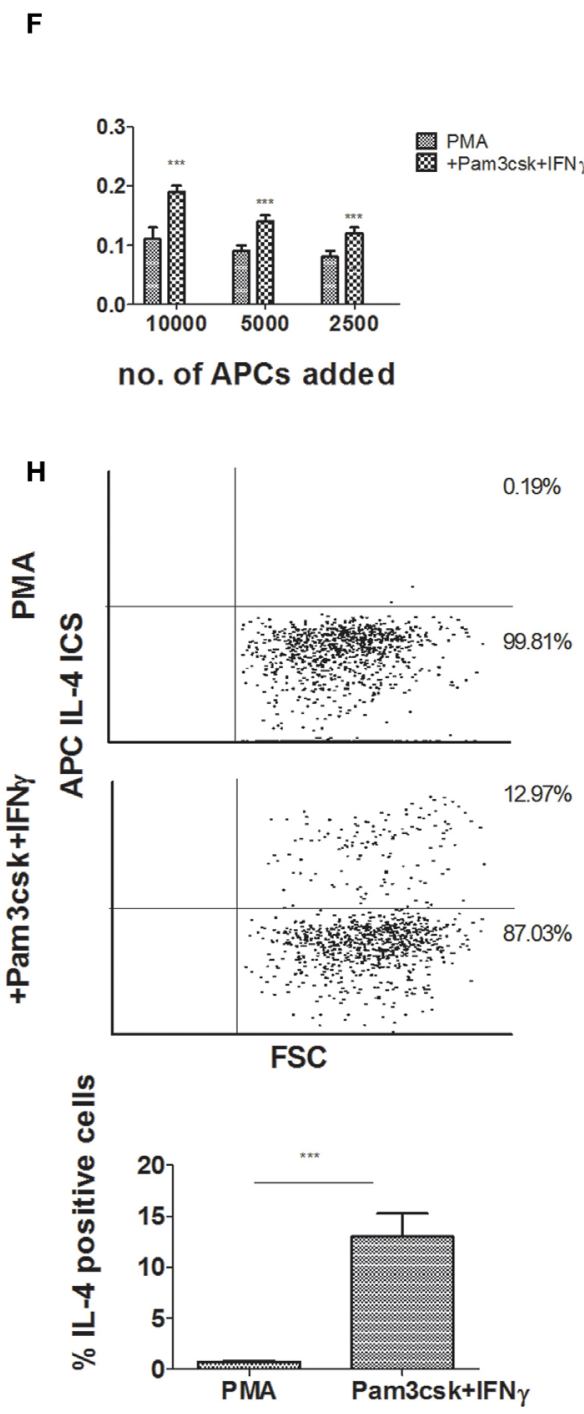

FIGURE 3 | Continued 
FIGURE 3 | Continued

Mixed lymphocyte reaction (MLR) responses using control vs. shMyD88-transduced antigen-presenting cells. Primary human CD4+ $T$ cells were isolated from buffy coats and activated by incubation with decreasing concentrations of shCnt, or shMyD88 THP-1 cells, previously differentiated with PMA, or PMA with the addition of Pam3csk4 + IFN $\gamma$. Cytokine production and proliferation were determined after 6 days of incubation. (A,B) IFN $\gamma$ production, (C,D) IL-17 production, and (E,F) proliferation. For panels (A-D), one representative experiment of three performed with similar results, is shown. For proliferation (E,F), the combined results of the three independent experiments are shown. In the proliferation studies (E,F), the ARU of T cells without THP-1 cells was close to 0 . (G,H) Flow cytometry analysis of intracellular IL-4 expression is presented for primary human CD4+ T cells stimulated by incubation with shCnt, or shMyD88 THP-1 cells, that were differentiated with PMA, or PMA with the addition Pam3csk4 + IFN $\gamma$ : (G) shCnt and $\mathbf{( H )}$ shMyD88 cells. One representative experiment of three independent MLR experiments is shown in the dot plots, and the average of the three experiments is shown in the bar graphs. The two-tailed $t$-test was used for statistical comparison.

A

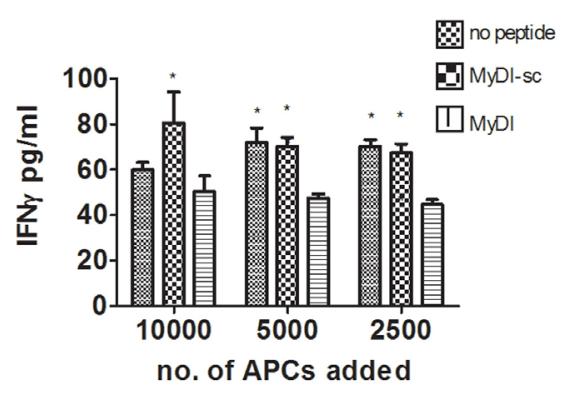

B

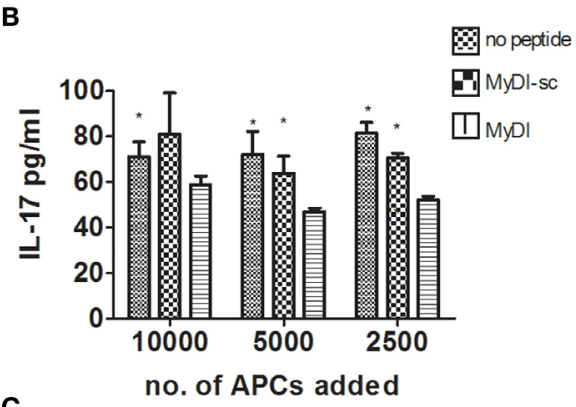

C

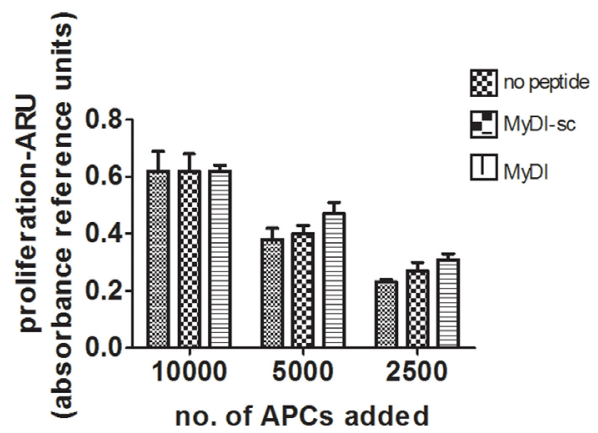

D
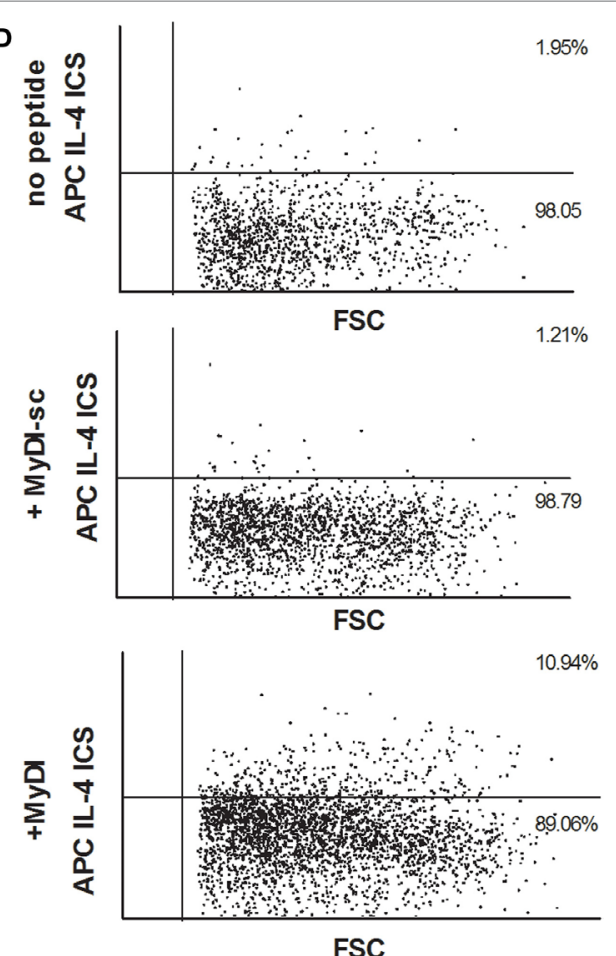

FSC

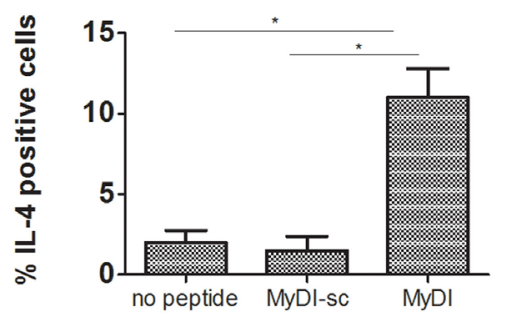

FIGURE 4 | Peptide inhibition of myeloid differentiation factor 88 in primary human antigen-presenting cells (APCs) leads to a shift in cytokine production by responding T cells. Primary monocytes were isolated from buffy coats and differentiated to macrophages for 6 days. Donor mismatched human $\mathrm{CD} 4^{+} \mathrm{T}$ cells were isolated from buffy coats and activated by incubation with decreasing concentrations of macrophages pretreated with or without MyDI/MyDI-sc $(80 \mu \mathrm{M})$. After 6 days of incubation, production of IFN $\mathbf{( A )}$ and IL-17 (B), and proliferation (C), were determined. Asterisks represent statistical comparison between the specified group vs. treatment with the $\mathrm{MyDI}$ peptide. For panels $\mathbf{( A , B )}$, one representative experiment of three independent experiments is shown. In panel (C), the proliferation of the three experiments was combined. Intracellular IL-4 expression was determined by flow cytometry (D). One representative experiment of three independent mixed lymphocyte reaction (MLR) experiments is shown in the dot plots, and the average of the three experiments is shown in the bar graphs. The two-tailed $t$-test was used for statistical evaluation.

LN T cell response to PPD. T cells from MyDI-treated animals secreted significantly less IFN $\gamma$ and IL-17 (Figures 6A,B), but greater amounts of IL-5 (Figure 6C). Since MyDI treatment influenced the T cell cytokine profile, we next tested the effect of MyDI administration on the clinical outcome of $\mathrm{MOG}_{35-55} /$ CFA-induced EAE. Mice were treated with MyDI or MyDI-sc 


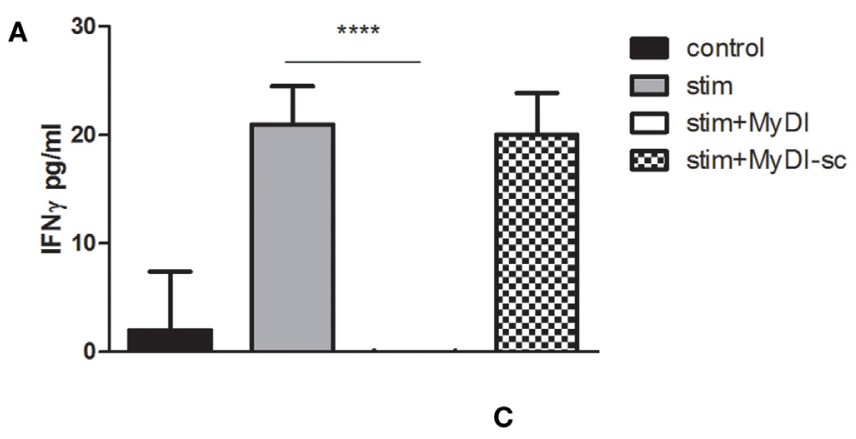

B

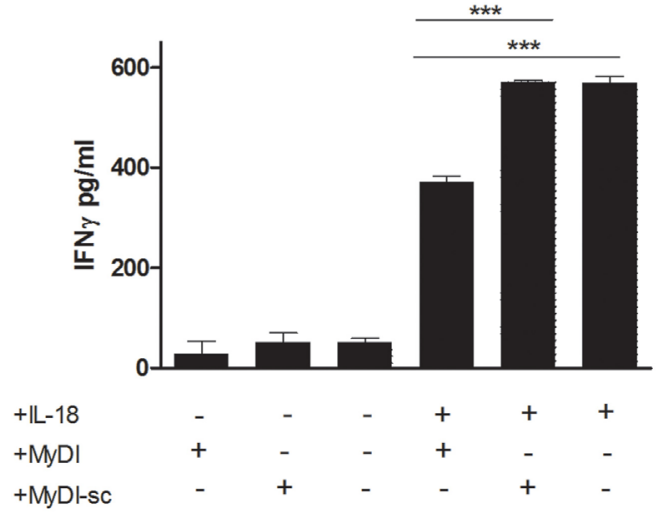

C

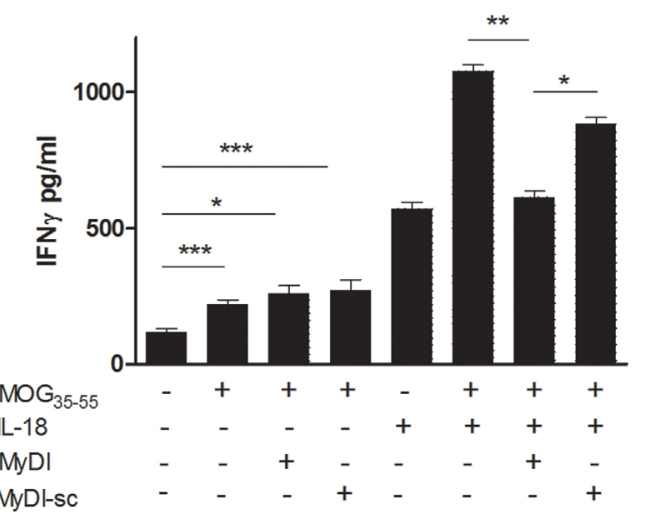

FIGURE 5 | Inhibition of myeloid differentiation factor 88 in murine and human T cells reduces IFN $\gamma$ production. (A) Primary human CD4+ T cells were isolated from buffy coats and stimulated with IL-18 + IL-12 (320 and $160 \mathrm{ng} / \mathrm{mL}$, respectively) overnight in the absence or presence of MyDI or MyDI-sc (20 $\mu \mathrm{M} / \mathrm{mL})$. The results are the average of triplicates and one representitve experiment of three independent experiments is shown. (B) Murine MOG35-55 specific T cells were incubated with MyDI or MyDI-sc $(20 \mu \mathrm{M} / \mathrm{mL})$ or without peptide for $2 \mathrm{~h}$. T-cells were then plated with or without $30 \mathrm{ng} / \mathrm{mL}$ IL-18 ON and IFN- $\gamma$ production was measured by ELISA. (C) MOG35-55 specific T cells were incubated with MyDI or MyDI-sc, or without peptide for $2 \mathrm{~h}$. T-cells were then plated with or without $30 \mathrm{ng} / \mathrm{mL}$ IL-18 ON in the presence of irradiated splenocytes and MOG35-55 peptide (5 $\mathrm{\mu g} / \mathrm{mL})$. The results are average of triplicates and representitve of two independent experiments. The two-tailed $t$-test was used for statistical evaluation.

$(2 \mathrm{mg} / \mathrm{kg})$ or PBS $(200 \mu \mathrm{L})$ i.p. three times a week beginning on the day of immunization with $\mathrm{MOG}_{35-55} / \mathrm{CFA}$. As shown in Figure 6D, MyDI treatment significantly reduced EAE disease severity.

\section{DISCUSSION}

Myeloid differentiation factor 88 is an adaptor protein that assembles a signaling complex at the intracellular domains of TLRs and the IL-1R superfamily, leading to the downstream activation of NF- $\kappa$ B and MAPKs $(11,17,18)$. MyD88-dependent signals, in both APCs and responding $\mathrm{T}$ cells, play a major role in determining the strength and character of $\mathrm{T}$ cell responses (19). MyD88-deficient mice are for the most part resistant to autoimmune disease, and are unable to reject minor- and major-mismatched allograft transplants (4, 20-22). However, we know less about the role of MyD88 in determining the outcome of human T cell responses, and clinical features of MyD88 deficiency in humans do not mimic the critical role played by MyD88 in mice. For example, MyD88-deficiency in humans enhances the sensitivity to infection by a narrow range of mostly pyogenic bacteria, in contrast to the broad-spectrum risk of infection in MyD88 knockout mice (23-26). Furthermore, the sensitivity to infection in individuals with inactivating mutations in MyD88 wanes with age, suggesting that MyD88 becomes redundant in the adult human response to infection. In this study, we explored the role of MyD88 in regulating the outcome of a human alloreactive MLR response. MyD88 knockdown human APCs expressed equivalent levels of MHC but decreased CD80 compared to control APCs in response to TLR2-induced maturation (together with IFN $\gamma$ ). MyD88 inhibition in human APCs (either a cell line or primary cells) did not affect the ability of the APCs to induce proliferation of alloreactive T cells in an MLR; however, the cytokine profile shifted from IFN $\gamma / \mathrm{IL}-17$ production, to IL-4 production. Reduced CD80 expression (without changes in CD86 expression) has been shown by others to correlate with a shift in the $\mathrm{T}$ cell response from IFN $\gamma$ production to IL-4 production, and with enhanced allograft survival (27). Inhibition of MyD88 in human APCs produced a similar outcome to that of alloreactive responses in mouse T-cells stimulated by DCs from MyD88-deficient mice (5), and our results are consistent with the shift to Th2-cytokines observed in multiple immunization studies using MyD88-deficient mice (28-30). In contrast, others have shown that the TRIF signaling pathway, rather than the MyD88 pathway, induces upregulated costimulatory molecule expression in mouse (31) or human (32) DCs. Our study ruled out TRIF involvement by differentiating APCs in the presence of the TLR2 ligand PAM3Csk4; however, we also found that 

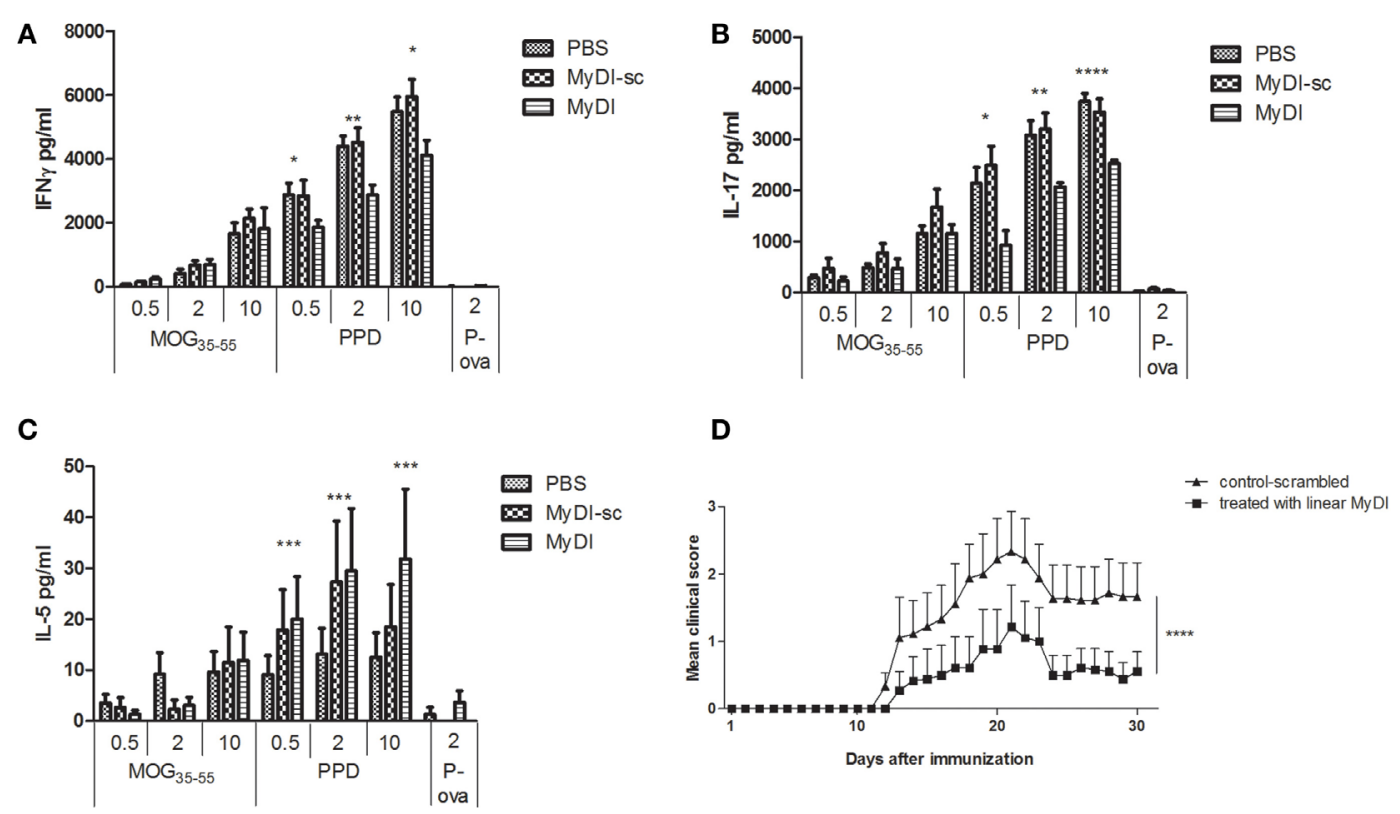

FIGURE 6 | MyDI administration in vivo alters the cytokine profile of responding T cells and ameliorates severity of experimental autoimmune encephalomyelitis (EAE). LNC were harvested 11 days after MOG35-55/CFA immunization. Groups were treated at day 0 and every $48 \mathrm{~h} \mathrm{i.p.} \mathrm{with} 2 \mathrm{mg} / \mathrm{kg}$ Mydl, or MyDI-scrambled or PBS as controls. Cells were plated and activated ex vivo with increasing doses of MOG35-55 or increasing doses of purified protein derivative (PPD; 0.5, 2, and $10 \mu \mathrm{g} / \mathrm{mL}$ ), or ovalbumin (OVA) peptide (2 $\mu \mathrm{g} / \mathrm{mL})$, an irrelevant antigen control. Cytokines were measured in the supernatants at $72 \mathrm{~h}$. LNC from animals treated with MyDI produced significantly less IFN- $\gamma$ (A) and IL-17 (B), but significantly more IL-5 (C), at all concentrations of PPD antigen. (A-C) Results are the average of triplicates and the two-tailed $t$-test was used for statistical evaluation. (D) Mice were immunized with MOG35-55/CFA on day 0, with PTX administration on days 0 and 2. Groups of mice were treated with $2 \mathrm{mg} / \mathrm{kg}$ MyDI (squares) or MyDI-sc/PBS (triangles). The graph shows differences in clinical scores between mice treated with MyDI and controls ( $n=9$ mice per group). Data are mean \pm SEM and significantly different by two-way analysis of variance (ANOVA).

MyD88, rather than TRIF, was responsible for costimulatory molecule expression and T-cell Th1-differentiation when LPS was used to differentiate the APCs (data not shown). To the best of our knowledge, this is the first demonstration of the role of MyD88 in a human alloreactive response, and our results indicate that MyD88 inhibition is sufficient to shift the phenotype of the $\mathrm{T}$ cell response to alloantigens.

Myeloid differentiation factor 88 signaling also controls T-cell responses intrinsically, both because of its role in the signaling of IL-1R family members expressed on $\mathrm{T}$ cells and because $\mathrm{T}$ cells express innate immune TLRs and respond to TLR ligands (33-35). In mouse T cells, intrinsic MyD88-signaling is essential for both early differentiation of Th17 cells (36) and for Th17 lineage commitment (37). IL-1 $\beta$, together with IL-6, induces Th17 polarization of naïve human $\mathrm{CD}^{+} \mathrm{T}$ cells independent of antigen stimulation (38). We found that MyD88 inhibition in human $\mathrm{CD}^{+} \mathrm{T}$ cells blocked IFN $\gamma$ production in response to IL-12 + IL-18 stimulation, confirming that MyD88 is not redundant for human T-cell responses to IL-1 family members. Similarly, MyD88 inhibition of mouse $\mathrm{T}$ cells in vitro reduced their response to IL-18. Thus, in the setting of antigen presentation, interventions that block MyD88-signaling can alter the character of the adaptive response by affecting the APCs, and/or the responder $\mathrm{T}$ cells directly. Given its role in determining T-cell phenotype, targeted inhibition of MyD88-mediated signaling represents an appealing therapeutic strategy for organ transplantation and autoimmune disease. Importantly, intra-peritoneal administration of the MyD88 inhibitory peptide to mice immunized with MOG/CFA was sufficient to significantly shift the cytokine response of lymph node T cells toward greater IL-5 production and less IFN $\gamma / \mathrm{IL}-17$ production. The cytokine shift observed in mice treated with the MyD88-inhibitor peptide correlated with significant amelioration of clinical disease. Similarly, protection in EAE afforded by helminth products is dependent on IL-5 (39). MyD88 is critical for the generation of proinflammatory autoimmune T-cells in response to immunization with autoantigens emulsified with adjuvants such as CFA, which contain TLR ligands $(6,40-42)$. We previously showed that $\mathrm{MOG}_{35-55} / \mathrm{CFA}$ immunization in $\mathrm{MyD} 88^{-/-}$mice induces autoimmune $\mathrm{T}$ cells that actively downregulate adoptively transferred encephalitogenic T cells; this suggests that inhibition of MyD88 can generate protective autoimmunity (6). However, since spontaneous EAE develops normally in $\mathrm{MyD}^{-/-}$, PLPTCR transgenic mice (43), adjuvants may be required to induce MyD88-independent signaling that can regulate autoimmunity. Our current findings support the idea that inhibition of Myd88 during an adjuvant-induced response enables a shift in the T cell cytokine profile. Since the majority of the immune response in $\mathrm{MOG}_{35-55} / \mathrm{CFA}$-immunized mice is against the foreign antigens of CFA, it is not surprising that systemic MyD88 inhibition influenced the response to $\mathrm{PPD}$, representing many immunodominant antigens of CFA. Mechanistically, MyD88 inhibition may produce a population of partially mature DCs that induce Th2 cells via a default pathway $(44,45)$. Alternatively, MyD88 
inhibition in the context of TLR signaling may lead to the secretion of mediators that directly promote Th2-cell differentiation (46). In any case, therapeutic strategies aimed at MyD88 need to account for the strength and kinetics of the response to the targeted antigen since these parameters influence Th cell development $(47,48)$.

Several groups have generated small molecule MyD88 inhibitors based on the MyD88 BB-loop seven amino acid peptide $(12,13)$. These drug candidates have wide-spread potential for use in sepsis, cancer, organ transplantation, and autoimmunity $(14,49,50)$. Targeted delivery of MyD88 inhibitors during peaks of Th1 immune reactivity is an attractive option to promote Th2 immunity to self-antigens.

\section{ETHICS STATEMENT}

All mouse experiments were approved by the Hebrew UniversityHadassah Institutional Animal Care and Use Committee, protocol number 16-14745.

\section{REFERENCES}

1. Zhu J, Yamane H, Paul WE. Differentiation of effector CD4 T cell populations (*). Annu Rev Immunol (2010) 28:445-89. doi:10.1146/ annurev-immunol-030409-101212

2. Sun J, Walsh M, Villarino AV, Cervi L, Hunter CA, Choi Y, et al. TLR ligands can activate dendritic cells to provide a MyD88-dependent negative signal for Th2 cell development. JImmunol (2005) 174(2):742-51. doi:10.4049/ jimmunol.174.2.742

3. Schnare M, Rollinghoff M, Qureshi S. Toll-like receptors: sentinels of host defence against bacterial infection. Int Arch Allergy Immunol (2006) 139(1):75-85. doi:10.1159/000090001

4. Wu H, Noordmans GA, O'Brien MR, Ma J, Zhao CY, Zhang GY, et al. Absence of MyD88 signaling induces donor-specific kidney allograft tolerance. J Am Soc Nephrol (2012) 23(10):1701-16. doi:10.1681/ASN. 2012010052

5. Kaisho T, Hoshino K, Iwabe T, Takeuchi O, Yasui T, Akira S. Endotoxin can induce MyD88-deficient dendritic cells to support T(h)2 cell differentiation. Int Immunol (2002) 14(7):695-700. doi:10.1093/intimm/dxf039

6. Cohen SJ, Cohen IR, Nussbaum G. IL-10 mediates resistance to adoptive transfer experimental autoimmune encephalomyelitis in MyD88(-/-) mice. J Immunol (2010) 184(1):212-21. doi:10.4049/jimmunol.0900296

7. Ochi A, Nguyen AH, Bedrosian AS, Mushlin HM, Zarbakhsh S, Barilla R, et al. MyD88 inhibition amplifies dendritic cell capacity to promote pancreatic carcinogenesis via Th2 cells. J Exp Med (2012) 209(9):1671-87. doi:10.1084/ jem.20111706

8. Zambirinis CP, Miller G. Signaling via MYD88 in the pancreatic tumor microenvironment: a double-edged sword. Oncoimmunology (2013) 2(1):e22567. doi:10.4161/onci.22567

9. Ohnishi H, Tochio H, Kato Z, Orii KE, Li A, Kimura T, et al. Structural basis for the multiple interactions of the MyD88 TIR domain in TLR4 signaling. Proc Natl Acad Sci U S A (2009) 106(25):10260-5. doi:10.1073/pnas.0812956106

10. Loiarro M, Ruggiero V, Sette C. Targeting TLR/IL-1R signalling in human diseases. Mediators Inflamm (2010) 2010:674363. doi:10.1155/2010/674363

11. Gay NJ, Gangloff M, O'Neill LA. What the Myddosome structure tells us about the initiation of innate immunity. Trends Immunol (2011) 32(3):104-9. doi:10.1016/j.it.2010.12.005

12. Loiarro M, Sette C, Gallo G, Ciacci A, Fanto N, Mastroianni D, et al. Peptidemediated interference of TIR domain dimerization in MyD88 inhibits interleukin-1-dependent activation of NF-\{kappa\}B. J Biol Chem (2005) 280(16):15809-14. doi:10.1074/jbc.C400613200

13. Hong EH, Chang SY, Lee BR, Kim YS, Lee JM, Kang CY, et al. Blockade of Myd88 signaling induces antitumor effects by skewing the immunosuppressive

\section{AUTHOR CONTRIBUTIONS}

GN supervised all experiments and wrote the manuscript together with SD. SD and SC designed and performed all experiments. IC provided conceptual advice and supervised some of the experiments.

\section{ACKNOWLEDGMENTS}

This work was supported by a grant from the Israeli Ministry of Science and Technology. We thank Dr. Luba Eli-Berchoier for technical assistance with many aspects of the work and the STEP Foundation for a student stipend to SD.

\section{SUPPLEMENTARY MATERIAL}

The Supplementary Material for this article can be found online at http://journal.frontiersin.org/article/10.3389/fimmu. 2017.00615/full\#supplementary-material.

function of myeloid-derived suppressor cells. Int J Cancer (2013) 132(12): 2839-48. doi:10.1002/ijc.27974

14. Olson MA, Lee MS, Kissner TL, Alam S, Waugh DS, Saikh KU. Discovery of small molecule inhibitors of MyD88-dependent signaling pathways using a computational screen. Sci Rep (2015) 5:14246. doi:10.1038/srep14246

15. Nadler C, Baruch K, Kobi S, Mills E, Haviv G, Farago M, et al. The type III secretion effector NleE inhibits NF-kappaB activation. PLoS Pathog (2010) 6(1):e1000743. doi:10.1371/journal.ppat.1000743

16. Munk RB, Sugiyama K, Ghosh P, Sasaki CY, Rezanka L, Banerjee K, et al. Antigen-independent IFN-gamma production by human naive CD4 T cells activated by IL-12 plus IL-18. PLoS One (2011) 6(5):e18553. doi:10.1371/ journal.pone.0018553

17. O'Neill LA. The role of MyD88-like adapters in toll-like receptor signal transduction. Biochem Soc Trans (2003) 31(Pt 3):643-7. doi:10.1042/bst0310643

18. Akira S, Takeda K. Toll-like receptor signalling. Nat Rev Immunol (2004) 4(7):499-511. doi:10.1038/nri1391

19. Kapsenberg ML. Dendritic-cell control of pathogen-driven T-cell polarization. Nat Rev Immunol (2003) 3(12):984-93. doi:10.1038/nri1246

20. Goldstein DR, Tesar BM, Akira S, Lakkis FG. Critical role of the Toll-like receptor signal adaptor protein MyD88 in acute allograft rejection. JClin Invest (2003) 111(10):1571-8. doi:10.1172/JCI17573

21. Tesar BM, Zhang J, Li Q, Goldstein DR. TH1 immune responses to fully MHC mismatched allografts are diminished in the absence of MyD88, a tolllike receptor signal adaptor protein. Am J Transplant (2004) 4(9):1429-39. doi:10.1111/j.1600-6143.2004.00544.x

22. Lerret NM, Li T, Wang JJ, Kang HK, Wang S, Wang X, et al. Recipient Myd88 deficiency promotes spontaneous resolution of kidney allograft rejection. J Am Soc Nephrol (2015) 26(11):2753-64. doi:10.1681/ASN.2014080813

23. von Bernuth $\mathrm{H}$, Picard C, Jin Z, Pankla R, Xiao H, Ku CL, et al. Pyogenic bacterial infections in humans with MyD88 deficiency. Science (2008) 321(5889):691-6. doi:10.1126/science.1158298

24. Conway DH, Dara J, Bagashev A, Sullivan KE. Myeloid differentiation primary response gene 88 (MyD88) deficiency in a large kindred. J Allergy Clin Immunol (2010) 126(1):172-5. doi:10.1016/j.jaci.2010.04.014

25. von Bernuth H, Picard C, Puel A, Casanova JL. Experimental and natural infections in MyD88- and IRAK-4-deficient mice and humans. Eur J Immunol (2012) 42(12):3126-35. doi:10.1002/eji.201242683

26. Alsina L, Israelsson E, Altman MC, Dang KK, Ghandil P, Israel L, et al. A narrow repertoire of transcriptional modules responsive to pyogenic bacteria is impaired in patients carrying loss-of-function mutations in MYD88 or IRAK4. Nat Immunol (2014) 15(12):1134-42. doi:10.1038/ni.3028

27. Hancock WW, Sayegh MH, Zheng XG, Peach R, Linsley PS, Turka LA. Costimulatory function and expression of CD40 ligand, CD80, and CD86 
in vascularized murine cardiac allograft rejection. Proc Natl Acad Sci U S A (1996) 93(24):13967-72. doi:10.1073/pnas.93.24.13967

28. Chen LZ, Hochwald GM, Huang C, Dakin G, Tao H, Cheng C, et al. Gene therapy in allergic encephalomyelitis using myelin basic protein-specific $\mathrm{T}$ cells engineered to express latent transforming growth factor-beta1. Proc Natl Acad Sci U S A (1998) 95(21):12516-21. doi:10.1073/pnas.95.21.12516

29. Muraille E, De Trez C, Brait M, De Baetselier P, Leo O, Carlier Y. Genetically resistant mice lacking MyD88-adapter protein display a high susceptibility to Leishmania major infection associated with a polarized $\mathrm{Th} 2$ response. J Immunol (2003) 170(8):4237-41. doi:10.4049/jimmunol.170.8.4237

30. Bello-Irizarry SN, Wang J, Johnston CJ, Gigliotti F, Wright TW. MyD88 signaling regulates both host defense and immunopathogenesis during pneumocystis infection. J Immunol (2014) 192(1):282-92. doi:10.4049/ jimmunol.1301431

31. Hoebe K, Janssen EM, Kim SO, Alexopoulou L, Flavell RA, Han J, et al. Upregulation of costimulatory molecules induced by lipopolysaccharide and double-stranded RNA occurs by Trif-dependent and Trif-independent pathways. Nat Immunol (2003) 4(12):1223-9. doi:10.1038/ni1010

32. Kolanowski ST, Dieker MC, Lissenberg-Thunnissen SN, van Schijndel GM, van Ham SM, ten Brinke A. TLR4-mediated pro-inflammatory dendritic cell differentiation in humans requires the combined action of MyD88 and TRIF. Innate Immun (2014) 20(4):423-30. doi:10.1177/1753425913498626

33. Zanin-Zhorov A, Nussbaum G, Franitza S, Cohen IR, Lider O. T cells respond to heat shock protein 60 via TLR2: activation of adhesion and inhibition of chemokine receptors. FASEB J (2003) 17(11):1567-9. doi:10.1096/ fi.02-1139fje

34. Zanin-Zhorov A, Tal G, Shivtiel S, Cohen M, Lapidot T, Nussbaum G, et al. Heat shock protein 60 activates cytokine-associated negative regulator suppressor of cytokine signaling 3 in $\mathrm{T}$ cells: effects on signaling, chemotaxis, and inflammation. JImmunol (2005) 175(1):276-85. doi:10.4049/ jimmunol.175.1.276

35. Reynolds JM, Pappu BP, Peng J, Martinez GJ, Zhang Y, Chung Y, et al. Tolllike receptor 2 signaling in CD4(+) T lymphocytes promotes T helper 17 responses and regulates the pathogenesis of autoimmune disease. Immunity (2010) 32(5):692-702. doi:10.1016/j.immuni.2010.04.010

36. Chung Y, Chang SH, Martinez GJ, Yang XO, Nurieva R, Kang HS, et al. Critical regulation of early Th17 cell differentiation by interleukin-1 signaling. Immunity (2009) 30(4):576-87. doi:10.1016/j.immuni.2009.02.007

37. Chang J, Burkett PR, Borges CM, Kuchroo VK, Turka LA, Chang CH. MyD88 is essential to sustain mTOR activation necessary to promote T helper 17 cell proliferation by linking IL-1 and IL-23 signaling. Proc Natl Acad Sci U S A (2013) 110(6):2270-5. doi:10.1073/pnas.1206048110

38. Acosta-Rodriguez EV, Napolitani G, Lanzavecchia A, Sallusto F. Interleukins lbeta and 6 but not transforming growth factor-beta are essential for the differentiation of interleukin 17-producing human T helper cells. Nat Immunol (2007) 8(9):942-9. doi:10.1038/ni1496

39. Finlay CM, Stefanska AM, Walsh KP, Kelly PJ, Boon L, Lavelle EC, et al. Helminth products protect against autoimmunity via innate type 2 cytokines IL-5 and IL-33, which promote eosinophilia. J Immunol (2016) 196(2):703-14. doi:10.4049/jimmunol.1501820
40. Sun J, Han X, Yu B. Synthesis of anemoclemoside B, the first natural product with an open-chain cyclic acetal glycosidic linkage. Org Lett (2005) 7(10):1935-8. doi:10.1021/ol050324y

41. Prinz M, Garbe F, Schmidt H, Mildner A, Gutcher I, Wolter K, et al. Innate immunity mediated by TLR9 modulates pathogenicity in an animal model of multiple sclerosis. J Clin Invest (2006) 116(2):456-64. doi:10.1172/JCI26078

42. Marta M, Andersson A, Isaksson M, Kampe O, Lobell A. Unexpected regulatory roles of TLR4 and TLR9 in experimental autoimmune encephalomyelitis. Eur J Immunol (2008) 38(2):565-75. doi:10.1002/ eji.200737187

43. Wexler AG, Frielle C, Berry G, Budgeon LR, Baccon J, Christensen ND, et al. The innate immune adaptor MyD88 is dispensable for spontaneous autoimmune demyelination in a mouse model of multiple sclerosis. J Neuroimmunol (2013) 255(1-2):60-9. doi:10.1016/j.jneuroim.2012.11.004

44. Langenkamp A, Messi M, Lanzavecchia A, Sallusto F. Kinetics of dendritic cell activation: impact on priming of TH1, TH2 and nonpolarized T cells. Nat Immunol (2000) 1(4):311-6. doi:10.1038/79758

45. Pletinckx K, Stijlemans B, Pavlovic V, Laube R, Brandl C, Kneitz S, et al. Similar inflammatory DC maturation signatures induced by TNF or Trypanosoma brucei antigens instruct default Th2-cell responses. Eur J Immunol (2011) 41(12):3479-94. doi:10.1002/eji.201141631

46. Kalinski P, Vieira PL, Schuitemaker JH, de Jong EC, Kapsenberg ML. Prostaglandin E(2) is a selective inducer of interleukin-12 p40 (IL-12p40) production and an inhibitor of bioactive IL-12p70 heterodimer. Blood (2001) 97(11):3466-9. doi:10.1182/blood.V97.11.3466

47. Boonstra A, Asselin-Paturel C, Gilliet M, Crain C, Trinchieri G, Liu YJ, et al. Flexibility of mouse classical and plasmacytoid-derived dendritic cells in directing Thelper type 1 and 2 cell development: dependency on antigen dose and differential toll-like receptor ligation. J Exp Med (2003) 197(1):101-9. doi:10.1084/jem.20021908

48. MacDonald AS, Maizels RM. Alarming dendritic cells for Th2 induction. J Exp Med (2008) 205(1):13-7. doi:10.1084/jem.20072665

49. Fekonja O, Avbelj M, Jerala R. Suppression of TLR signaling by targeting TIR domain-containing proteins. Curr Protein Pept Sci (2012) 13(8):776-88. doi:10.2174/138920312804871148

50. Kissner TL, Ruthel G, Alam S, Mann E, Ajami D, Rebek M, et al. Therapeutic inhibition of pro-inflammatory signaling and toxicity to staphylococcal enterotoxin B by a synthetic dimeric BB-loop mimetic of MyD88. PLoS One (2012) 7(7):e40773. doi:10.1371/journal.pone.0040773

Conflict of Interest Statement: The authors declare that the research was conducted in the absence of any commercial or financial relationships that could be construed as a potential conflict of interest.

Copyright $\odot 2017$ Dishon, Cohen, Cohen and Nussbaum. This is an open-access article distributed under the terms of the Creative Commons Attribution License (CC BY). The use, distribution or reproduction in other forums is permitted, provided the original author(s) or licensor are credited and that the original publication in this journal is cited, in accordance with accepted academic practice. No use, distribution or reproduction is permitted which does not comply with these terms. 